\section{Alice Mary Stewart (Maisie) Fitter: 1912-1996}

Maisie Fitter, who died on 9 April, will be sorely missed by her many friends and colleagues in the conservation movement. She was well-known to the majority of members of Fauna \& Flora International because, in many ways, she provided the image of the Society for many years. This very journal, Oryx, and its quality owes its high standards to Maisie. Her editorial skills and ability to reduce long and complicated - often, sad to say, rambling - conservation messages and information into short, sharp, clear paragraphs was but one of the strengths she brought to FFI and the conservation movement in general. In 1963, when she became the Editor, she set about honing Oryx into the primary source of conservation news and opinion that it remains to this day.

On her 'retirement' in 1982, when I was Chairman of the Species Survival Commission (SSC), she kindly agreed to take on the task of creating and maintaining the Commission's newsletter, Species, which also continues to go from strength to strength.

To think of Maisie as 'just an editor' would, however, be a grave mistake. Skilful as she was, she also built a world-wide network of contacts, who trusted her not only with their news but also to produce it in a way that ensured that, in a few words, it would produce maximum effect. It is true to say that Maisie was 'networking' long before it became the buzz word of today.

In looking back, there is no doubt that Maisie's direct, no-nonsense but humorous way stems from her upbringing. Born in Abbey Town, Cumberland, the daughter of a local doctor, she spent her early years in Huddersfield, West Yorkshire. She graduated from Bedford College, London, in 1934, having studied history, and set off on her journalism straight away as assistant editor of the Sunday School Chronicle, where she remained until 1941.

She married Richard in April 1938 and so their life-long partnership began. In 1946 she joined the Countryman, working with its founder, J. W. Robertson-Scott. With both she and Richard now working at the Countryman, they lived in Burford in the old coaching inn in Sheep Street, which still serves as offices for the magazine. This is where the other side of Maisie's activities began to emerge, as a passionate and skilled gardener. Years later, when visiting their Chiltern home at Chinnor Hill, to discuss with Maisie the next issue of Species, we would first tour the garden to see the latest treasures to flower. This for me has formed part of the many happy memories of our years of fruitful collaboration.

Maisie's friendships were deep and lifelong. She had another north-country trait, however: she could not stand wafflers and would provide a rapier-like, deflationary statement, which others often wished they had delivered and which the recipient fully realized meant, next time keep it simple and succinct!

Maisie was a voluntary conservationist working on a world stage, which was recognized by her being made a Member of Honour of the Species Survival Commission and also an officer of the Order of the Golden Ark. For Maisie, conservation began at home and she was a very keen and active member of the County Naturalists Trust movement. She was, in fact, a founder member of the Berkshire, Buckinghamshire and Oxfordshire Naturalists Trust (BBONT, 1959) and, as one might expect, was editing the Trust's newsletter until 1970. In 1971 she succeeded Dr Bruce Campbell as Deputy Chairman of Council, becoming Chairman in 1975, a post she held until 1980. Subsequently she was elected Honorary VicePresident.

Maisie's legacy to conservation is large and subtle. Key elements that have been passed on through her colleagues and friends all focus on a deceptively simple concept: to win conservation battles you need accurate, succint data, which you present clearly and forcefully to as many audiences as possible. BBONT, Oryx and FFI, Species and SSC all, to this day, bear signs of her positive influence, no bad memorial for the future.

Gren Lucas 